\title{
Determinants of Motivation for Individual Instrument Class of University Students Studying Music Teaching
}

\section{Research Article}

\section{Dilek OZCELIK HERDEM ${ }^{1}$}

${ }^{1}$ Gazi University, Faculty of Education, Department of Music Education, ORCID: 0000-0002-9894-8152

To cite this article: Herdem, D. O. (2020). Determinants of Motivation for Individual Instrument Class of University Students Studying Music Teaching, International Online Journal of Educational Sciences, 12(3), 90-109.

\section{ARTICLE INFO \\ Article History: \\ Received: 25.12 .2019 \\ Available online: \\ 28.06.2020}

\begin{abstract}
The aim of this study is to determine the level of motivation for individual instrument class and to identfiy the determinants. Motivation for individual insturment class is quite newly researche in literature. Upon literature analysis, it is considered significant to determine whether motivation for individual instrument class differs by university, class, gender, and acoomodation. Moreover, in order to determine whether students' academic self-efficacy, mindfulness, and daily goals predict motivation for individual instrument class, regression analysis is employed in the study. The sample of the study consists of 225 students studying music teaching in Gazi University and Erzincan Binalı Yıldırım University. As a result of this study, it is found out that amotivation differs by university, academic self-efficacy predicts amotivation, motivation for achievement, and motivation for study, mindfulness predicts amotivation and motivation for achievement, and daily goals predicts motivation for study. Findings are discussed and some recommendations for further research are made.
\end{abstract}

(C) 2020 IOJES. All rights reserved

\section{Keywords:}

Music, Education, Motivation for Individual Instrument Class, Academic Self-Efficacy, Mindfulness, Daily Goals.

\section{Introduction}

The education of music as a branch of fine arts, in which science and art are intertwined, is always considered important by contemporary societies. The value and importance of music, as both science and art, is evident in conveying the common feelings and thoughts of humanity and creating a common language. For this reason, it is thought that music education is a necessity in order to improve the education aspect and to be taught with scientific methods within a certain systematic to get more benefits. Music education which is an educational field surrounded by many teaching fields, is determined as a study area where music is learned and taught. In this field, when the music education is received by students, the musical perception ability of students should be diversified especially (Sak, 1997). One of the most indispensable branches of music

\footnotetext{
${ }^{1}$ Corresponding author's address: Gazi University, Faculty of Education, Department of Music Education, Ankara, Turkey 
education is individual instrument playing, which contributes to the concrete development of musical perception ability and and requires the use of musical education, psychomotor and emotional skills together.

Instrument education could be described as "the whole set of methods created to reach musical expression based on technical basis" Herdem (2018, p. 945). It is very important and necessary for the music teacher candidate to prepare for the profession and to be a successful music educator with the courses given under the name of "individual instrument class" in the institutions of the universities training music teachers. As the teacher is a role-model for students, playing individual instrument has an encouraging and enthusiastic aspect. Hence, the instrument is a valuable teaching material. Moreover, the use of an instrument provides great convenience in the efficient music teaching,

The instrument training, which requires integrating physical, cognitive and emotional skills together in a coordinated way, is a very difficult process. In order to produce successful performances, instrument training is a planned, intensive and regular performance course that requires long hours of practice in a certain discipline, and it is very important to continue the practices regularly without any interruption. When the practicing is somehow disrupted, it is reflected negatively on the performance of the instrument as soon as possible.

Foundation of motivation is meeting the requirements of individuals. To this end, students would be efficiently motivated if the factors that affect the requirements were determined (Küçükosmanoğlu, 2015). According to Uçan (2017), during this learning process students are to meet the requirements listed here: (1) a safe accommodation, (2) self-regulating, (3) balanced and mindful life, (4) competency development, (5) capability enabling, (6) exploitation of opportunities, (7) self-confidence, and (8) self-esteem. However, there is a scant literature on self-regulating strategies of students studying music teaching to motivate themselves for individual instrument class. Girgin (2015) is the first study to research motivation for individual instrument class in Turkish cultural context. Girgin (2017) examines individual instrument self-efficacy of students in accordance with demographic factors, Gerçeker (2018) studies burnout of students related to individual instrument performance, and Herdem (2019) measures the effect of psychological capital on motivation for individual instrument class. Common point of the studies is the need for further studies in order to more clarify the literature on motivation for individual instrument class.

The functions of the research on music are determining, describing, explaining, predicting, controlling, and evaluating (Uçan, 2017, p. 14). To this end, this study aims at contributing to the literature on motivation for individual instrument class by determining, describing, explaining, and predicting it by means of a crosssectional survey-based empirical study. The rest of the study is formed as follows. Following chapter discusses conceptual background while next chapter introduces research model. Aftermath, findings are displayed and discussed. Finally, conclusion chapter gives comparison the findings with current literature and makes recommendation for further research.

\section{Theoretical Discussion}

\section{Motivation for Individual Instrument Class}

Regular practice of an instrument as a part of daily routines and performing repetitions require a strong intrinsic motivation. According to Sungurtekin (2010), motivation is defined as the individual's determination to act decisively by having an inner strength and desire to achieve the goals. Similarly, motivation is effort, decisiveness, and skill management displayed by an individual to complete an activity (Pintrich \& Schunk, 2000). With a perspective of process, motivation is the process through which activities for desired end-state are definitely sustained (Schunk et al., 2008, p. 4). 
Motivation in schools is a process affected by individuals' as well as contextual factors such as learning environment (Ennis, 2017, p. 245). Motivation for a student is the degree of influence on the self to continue school life and attain the desired grade (Clark \& Schroth, 2010). Then, it is not wrong to say that in order for students to actively participate in learning process and to have the will to improve skills require high motivation (Şeker, 2017). Motivation direct individual through specific goals and urge them to achieve the desired end state.

There are not many motivation studies on the students studying music teaching. Küçükosmanoğlu (2015) reports high levels of motivation and lower level of amotivation. Şeker (2017) measures academic motivation levels of university students studying music teaching at an average level (69.39 out of 100). Herdem (2019) reports a quite high mean for motivation for achievement while an average level for motivation for study and a lower level for amotivation.

According to Şeker (2017) and Herdem (2019), motivation levels of students don't differ by gender. On the contrary, Onuk (2007), Eroğlu and colleagues (2017) report that motivation of female students is significantly higher than that of male ones. On the other hand, Küçükosmanoğlu (2015) finds out that intrinsic motivation of male students is higher whilst extrinsic one is less than females. Regarding class of the students, Eroğlu and colleagues (2017), Şeker (2017) reveal that academic motivation doesn't differ by class. On the other hand, Küçükosmanoğlu's (2015) study shows that amotivation levels of senior students are higher with respect to other students. Similarly Herdem (2019) states that freshman differs from seniors regarding motivation for achievement. Herdem (2019) also reports no significance difference related to university.

\section{Daily Goals}

Students' motivation will help them to have a regular working pace of the instrument study process (Brophy, 1998; Sabuncuoğlu \& Tuz, 1998; Sternberg \& Williams, 2002). At this point, it is important to determine daily goals related to the process of the student's instrument in guiding motivation and using it effectively. Indeed there are two sorts of goals; long-term goals related to future expectations and short-term daily goals (King, Richards, \& Stemmerich, 1998). Daily goals are set for a smooth and effortless transition to long-term life goals (Emmons, Colby, \& Kaiser, 1998). Daily goals are considered significant in order to display expected behavior towards achievement (Bakioğlu \& Çapan, 2015).

It is clear that regular long-term practice is required in acquisition of skills to play and individual instrument. As a matter of fact, the success of long-term goals requires a clear planning of daily goals and daily schedule (Emmons et al., 1998). It is not wrong to say that setting a daily goal is the first step towards long-term success that require a high level of performance skills. Daily goals a bridge role for university students to realize their long-term goals, to increase life satisfaction, and raise their awareness (Bakioğlu \& Çapan, 2015, p. 65). As Schunk (1995) asserts, goals are directly related with motivation and goals affect behaviors through motivation (Locke \& Latham, 1990). King's (2016) study provides enough evidence that goal orientations enhance the students' academic motivation. Zhang, Cao, Shen and Qian (2019) confirm positive effect of goal orientation on research motivation. Moreover, Zimmerman, Bandura and Martinez-Pons (1992) assert that the students, who set challenging goals and enlist self-regulating strategies, motivate themselves to achieve the goals. In addition, the results of Mikami's (2017) study show that goal commitment and difficulty directly affect intrinsic motivation while goal specificity doesn't have any direct effect on motivation. In compliance with literature, it may be hypothesized that the more oriented university students studying music are through daily goals the higher motivation for individual instrument class they have.

\section{Academic Self-Efficacy}

It is obvious that the individual needs to be emotionally durable in the process of learning instrument performance that requires physical and mental practice for long hours, ensuring daily and regular work, and 
creating a positive sense of self-efficacy. In addition, it is also reported that the expectation of positive selfefficacy increases motivation, thus enabling willingly coping with difficulties (Jerusalem, 2002). Self-efficacy, introduced to literature by Bandura (1977) under social cognitive theory and early discussed in academic settings by (Pajares, 1996), is self-belief of the student to be able to achieve academic success resulting from achievement-oriented behavior. In Bandura's (1994) words, self-efficacy is about capability of planning, organizing, and completing an activity. Self-efficacy leads to behavior following evaluation of skills and capabilities (Schunk \& Pajares, 2009). However, reminding situational awareness, not only invidiual but also organizational and environmental factors affect the perception of self-efficacy (Bandura, 2012). Thus, selfefficacy is context-specific as well as task-oriented (Ersanlı, 2015).

Academic self-efficacy is always considered an attractive research subject for researchers (Zimmerman et al., 1992). Öncü (2012) reviews literature and summarizes basic characteristics of academic self-efficacy as: (1) a judgment on achieving a specific task, (2) a multi-dimensional construct, (3) context-specific, and (4) measured by specified performance indicator, i.e. academic success. Regarding university students studying music, Girgin (2017) conducts a descriptive study on music teacher candidates' instrument performance selfefficacy belief levels and reports that. Deniz \& Kurucu (2019) finds out that students' self-efficacy perception incrementally increases once they have experience what to do and how to do. Seker (2014, p. 144) conclude that the candidates of music teachers have both moderate attitudes towards academic self-efficacy and playing instruments.

Self-efficacy affects the quality of life and influences quality and quantity how individuals motivate themselves (Bandura, 2012, p. 13). A positive self-efficacy with a high motivation leads to cope with challenging tasks and raises awareness to show great effort to succeed (Schunk, 1991; Bandura, 1993, 1997; Schunk \& Pajares, 2002; Hsieh, Sullivan \& Guerra, 2007; Alivernini \& Lucidi, 2011; McGeown et al., 2014; Hwang, Choi, Lee, Culver, \& Hutchison, 2015; Arık, 2019). Bandura (1997) contends that self-efficacy plays a larger role in motivation. Zimmerman \& Kitsantas (1999) reports a high correlation between self-efficacy and intrinsic motivation in a motoric learning task. Moreover Şeker (2017) reports that there is a moderate correlation between academic motivation and self-efficacy and the latter explains $13 \%$ of variance in the former. Likewise Eroğlu, Yıldırım, \& Şahan (2017) find out a high positive correlation between the two. And Zimmerman (2000) highly recommends teachers to promote self-efficacy in order to motivate the students to learn. In compliance with literature, it may be hypothesized that the higher academic self-efficacy of university students studying music is the higher motivation for individual instrument class they have.

\section{Mindfulness}

Mindfulness is a relatively new concept in educational research and there is an ever growing interest in last decades (Kabat-Zinn, 2000; Baer, Smith, \& Allen, 2004; Roeser, 2016). Many studies on the achievement of spiritual well-being focus on the importance and the need to improve the state of "mindfulness", which can be summarized as "awareness of what is happening at the moment" (Kabat-Zinn, 2000; Mayer, 2000; Brown \& Ryan, 2003; Baer et al., 2004; Lykins \& Baer, 2009). Mindfulness is keeping one's focus on what's happening at the moment regadless of considering either the past or the future (Kabat-Zinn, 1994). In other words, mindfulness is bringing one's attention to the present on purpose in a nonjudgmental and accepting way of experience (Lykins \& Baer, 2009, p. 226). Bishop and colleagues (2004) elaborates the definition and explains it as a process of regulating attention to bring quality of relating one's experience within acceptance. Baer and colleagues (2004) highlight common characteristics of mindfulness definitions and practices as; observing, describing, acting with attention, and accepting without judgment. In short, mindfulness is about intentional, nonjudgmental, and instantenous attention (Kabat-Zinn, 2004).

It is considered significant for students attending individual instrument class to develop mindfulness skills to have a positive continuum mentally, physically and emotionally as a whole in this difficult process. 
Because the students who are more engaged are likely to regularly attend courses and achieve academically (Sukhsarwala, Kacker, \& Mukundan, 2015; Pohl, 2020). Indeed, one of the outcomes in relation to mindfulness is motivation and learning taken place in mindfulness-based programs for students (Roeser, 2016, p. 385). In compliance with argument forwarded by Prinz, Beisert and Herwig (2013), mindfulness assist students to be motivated through academic achievement. Corti \& Gelati (2019) confirm the argument and apply mindful effective learning program to university students and conclude that the program help the students to improve self-confidence regarding learning abilities.

It is generally accepted that the more mindful one is the higher resilience about coping with stress one has (Weinstein, Brown and Ryan., 2009). There is enough evidence that mindful improves students' well-being and reduce stress, distress, and rumination (Roeser, 2016, p. 396). Moreover, individuals with higher levels of awareness show self-regulated fucntioning (Levesque \& Brown, 2007, p. 285). Demir (2017) observes that the anxiety levels of students decrease as a consequence of the therapy performed by applying mindfulness-based cognitive techniques. Üstün (2019, p. 591) highlights that students' daily and regular practice without interrupting could eliminate many problems encountered in the process of reaching the specified goals and to develop stress control and conscious awareness through the study. In compliance with literature, it may be hypothesized that the more mindful university students studying music are the higher motivation for individual instrument class they have.

\section{Research Methodology}

The aim of this study is to identify motivation levels of the students for individual instrument class, to determine the predictors of motivation for individual instrument class, and to examine whether it differs by any demographic factors such as gender, class, university, and accommodation. To this end, the research model is depicted on Figure-1.

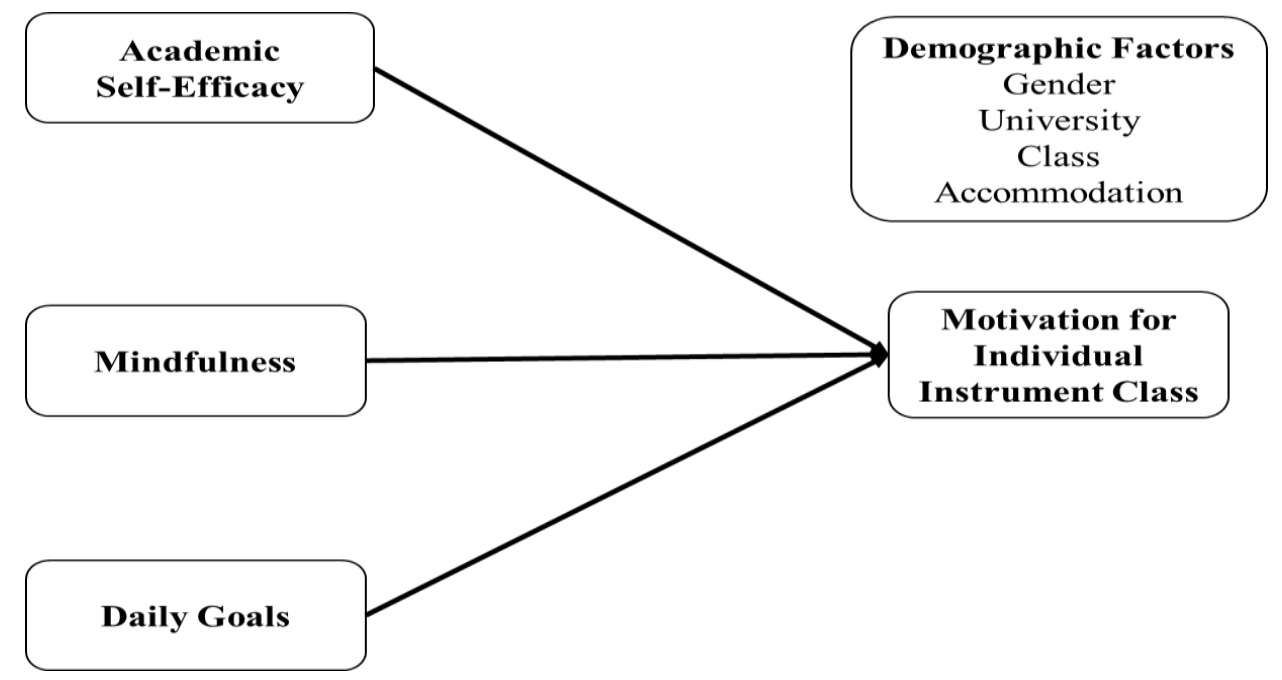

Figure 1. Research Model

The hypotheses with regard to literature are produced as follows:

H1: Motivation for individual instrument class differs by demographic factors.

H2: Self-efficacy of students predicts motivation for individual instrument class.

H3: Mindfulness predicts motivation for individual instrument class.

H4: Daily goals predict motivation for individual instrument class. 


\section{Study Group}

The population of the study is students studying music teaching at faculty of education in Gazi University and Erzincan Binali Yıldırım University universities in 2019-2020 fall semester. Total numbers of students are enrolled to both universities is 351 . Questionnaires were distributed to all students and 252 forms were returned. After excluding uncompleted questionnaires and outliers, analyses are done a sample of 225 students. Adequate sample size is computed as 184 at the significance of $5 \%$ with a confidence interval of $5 \%$. In this end, descriptive statistics related to demography are given on Table 1.

Table 1. Descriptive Statistics on Demography

\begin{tabular}{lccccc}
\hline Universities & Frequency & $\mathbf{\%}$ & Gender & Frequency & $\mathbf{\%}$ \\
\hline Gazi University & 149 & 66.2 & Male & 117 & 52.0 \\
\hline Erzincan Binali Yildırım University & 76 & 33.8 & Female & 108 & 48.0 \\
\hline \multicolumn{1}{c}{ Accommodation } & Frequency & $\mathbf{\%}$ & Class & Frequency & $\mathbf{\%}$ \\
\hline Staying with friends at home & 72 & 32.0 & Freshman & 63 & 28.0 \\
Living with family & 82 & 36.4 & Sophomore & 64 & 28.4 \\
Staying at state run quarters & 39 & 17.3 & Middler & 57 & 25.3 \\
Staying at private sector quarters & 32 & 14.2 & Senior & 41 & 18.2 \\
\hline
\end{tabular}

All students study music teaching at faculty of education in Gazi University and Erzincan Binali Yildırım University. 149 students (66.2\%) are enrolled in the former while 76 students (33.8) study in the latter. 117 students $(52.0 \%)$ responding questionnaire are male where the rest is female $(n=108,48.0 \%)$. Regarding classes, $28.0 \%$ of the students $(n=63)$ participating in the study is freshman while 64 students (28.4) are sophomore, 57 ones $(25.3 \%)$ are middler, and the rest is senior $(n=41,18.2 \%)$. Concerning accommodation, $32.0 \%$ of the students participating in the study $(\mathrm{n}=72)$ stay with friends at home, $36.4 \%(\mathrm{n}=82)$ lives with family, 39 students $(17.3 \%)$ stay in dormitory run by the state, and 32 students $(14.2 \%)$ stay in the private dormitory.

\section{Scales}

Validity and reliability of motivation for individual instrument class scale was conducted by Girgin (2015). A 5-point Likert scale is preferred in the questionnaire and participants are asked to mark to what extent they agree with given statements ( $1=$ Totally disagree, ..., $5=$ Totally agree). As a result of exploratory factor analysis, the researcher concludes that the scale consists of 25 items with a 3 factor model. Subfactors are called amotivation, motivation for achievement, and motivation for study, respectively. Cronbach Alpha coefficients for the subfactors are $0.90,0.88$, and 0.76 respectively, where that for the whole scale is 0.77 .

Academic self-efficacy was adapted from Jerusalem and Schwarzer (1981) by Y1lmaz and colleagues (2007) to Turkish. One question is reversely coded. A 5-point Likert scale is preferred in the questionnaire and participants are asked to mark to what extent they agree with given statements (1=Totally disagree, ..., $5=$ Totally agree). After translation of German-origin scale into Turkish, it was empirically tested with a sample of 672 university students and found out that one-factor structure with seven items be valid and the reliability coefficient for the scale was 0.79 .

Özyeşil, Arslan, Kesici and Deniz (2011) adapted mindfulness scale from Brown and Ryan (2003) into Turkish. A 6-point Likert scale is used and participants are asked to mark to what extent they agree with given statements ( $1=$ Almost never, ..., $6=$ Almost always). After conducting exploratory and confirmatory factor analyses, one-factor model with 15 items is found reliable and valid for the use of the scale in Turkish at studies with a sample of university students. Cronbach Alpha coefficient is computed as 0.80 . 
Daily goals scale was adapted by Bakioğlu and Çapan (2015) with exploratory and confirmatory analyses at two different samples. A 5-point Likert scale is preferred in the scale and participants are asked to mark to what extent they agree with given statements ( $1=$ Totally disagree, ..., $5=$ Totally agree). The scale consists of 13 items and shows a one-factor structure. The scale is found reliable that Cronbach Alpha coefficient is 0.80 .

All scales for the variables found reliable and valid for university students within Turkish cultural context. Therefore, the construct validity in this study is analyzed by confirmatory factor analysis and Cronbach Alpha coefficient is employed to test the reliability. Confirmatory factor analyses' results are shown in Table 2.

Table 2. Validity Analysis for Measurement Scales

\begin{tabular}{lcccccc}
\hline Measurement Model & $\chi^{2}$ & s.d. & $\chi^{2 / s . d .}$ & RMR & CFI & RMSEA \\
\hline Motivation for Individual Instrument Class & 982.425 & 272 & 3.612 & 0.059 & 0.876 & 0.108 \\
Three-Factor Related Modified Model & 633.613 & 267 & 2.373 & 0.057 & 0.936 & 0.078 \\
\hline Academic Self-Efficacy & 82.756 & 14 & 5.914 & 0.076 & 0.853 & 0.148 \\
One-Factor Modified Model & 21.573 & 11 & 1.961 & 0.036 & 0.977 & 0.066 \\
\hline Mindfulness & 222.395 & 90 & 2.471 & 0.131 & 0.892 & 0.081 \\
One-Factor Modified Model & 66.617 & 63 & 1.057 & 0.078 & 0.997 & 0.016 \\
\hline Daily Goals & 324.147 & 65 & 4.987 & 0.066 & 0.828 & 0.133 \\
One-Factor Modified Model & 123.015 & 54 & 2.278 & 0.045 & 0.954 & 0.076 \\
\hline Good fit values & & & $<3$ & $<0.05$ & $<0.95$ & $<0.05$ \\
Acceptable fit values & & & $<5$ & $<0.08$ & $<0.90$ & $<0.08$
\end{tabular}

$\chi^{2}$ : Chi-square; s.d .: Degree of freedom; RMR: Root mean square residual; CFI: Comparative Fit Index; RMSEA Root Mean Square Error of Approximation.

* Browne \& Cudeck, 1993; Byrne 2001; Kline, 2004; Schumacher, \& Lomax, 2004.

The fit indices of the scales are given in Table 2 with threshold values for each indicator (Browne \& Cudeck, 1993; Byrne 2001; Kline, 2004; Schumacher \& Lomax, 2004). The table gives base model at the first row for each scale and modified ones at the second. Once the indices are not initially fallen within acceptable, each scale is modified in accordance with indicators produced by AMOS software. Regarding motivation for individual instrument class, three-factor related model is confirmed in line with Girgin (2015). One factor models of the other scales are confirmed as proposed by Yllmaz and colleagues (2007) for self-efficacy, by Özyeşil et al. (2011) for mindfulness, and by Bakioğlu and Çapan (2015) for daily goals. However, one item is removed form mindfulness scale in order to modify it.

Provided all measurement scales are structurally confirmed by means of confirmatory factor analysis, Cronbach Alphas are computed to check reliability of the scales. According to Nunnaly (1978), the scale is considered reliable when Cronbach Alpha is equal to or greater than 0.70. SPSS software is employed to compute coefficients. Cronbach Alpha for motivation is 0.753 . Once three-factor related model is confirmed, Cronbach Alpha for each sub-factor is computed as well. Cronbach Alpha for amotivation 0.944 is while that for motivation for achievement is 0.896 and for motivation for study is 0.949 . Academic self-efficacy's reliability value is 0.793 . Reliability analysis for mindfulness produces a coefficient number as 0.887 , and for daily goals it is 0.909 . Since reliability analysis for all scales result in Cronbach Alphas greater than threshold value $(0.70)$, they are considered reliable. 


\section{Findings}

\section{Normality Analysis}

In order to determine whether motivation for individual instrument class, academic self-efficacy, mindfulness and daily goals show normal distribution in the study, Kolmogorov-Smirnov (K-S) Test were applied and the results along with descriptive statistics are given in Table 3. Mean of motivation of the students for individual instrument class is 3.13 out of 5 with a standard deviation of 0.37 . Regarding subfactors, the highest mean is of motivation for achievement ( $\mathrm{x}_{\mathrm{avg}}=4.50$, s.d. $\left.=0.68\right)$ while the least is of amotivation $\left(\mathrm{x}_{\mathrm{avg}}=1.52\right.$, s.d.=0.79). On the other hand, mean of motivation for study is 3.62 with a standard deviation of 0.93 .

Table 3. Normality Test Results

\begin{tabular}{lccccc}
\hline & & $\begin{array}{c}\text { Motivation for } \\
\text { Individual } \\
\text { Instrument Class }\end{array}$ & $\begin{array}{c}\text { Academic } \\
\text { Self-Efficacy }\end{array}$ & Mindfulness & Daily Goals \\
\hline Explanation & Mean & 225 & 225 & 225 & 225 \\
\hline Normal Parameters & Std. & 0.13 & 3.73 & 3.65 & 3.79 \\
& Deviation & & 0.70 & 0.94 & 0.69 \\
\hline Most Extreme Differences & Absolute & 0,076 & 0,098 & 0,023 & 0,046 \\
& Positive & 0,076 & 0,045 & 0,046 & 0,095 \\
& Negative & $-0,067$ & $-0,023$ & $-0,028$ & $-0,098$ \\
\hline Kolmogorov-Smirnov Z & & 1,245 & 1,269 & 1,214 & 1,342 \\
\hline Asymp. Sig. (2 tailed) & & 0,075 & 0,123 & 0,102 & 0,095 \\
\hline
\end{tabular}

Academic self-efficacy of the students is 3.73 on average with a standard deviation of 0.70 . Mean mindfulness level of the students is 3.65 out of 6 with a standard deviation of 0.94 . Likewise mean of daily goals is 3.79 out of 5 with a standard deviation of 0.69 .

K-S value for motivation for individual instrument class scale is 1.245 ( $\mathrm{p}>0.05)$, for academic self-efficacy scale is 1.269 ( $p>0.05$ ), for mindfulness scale is 1.214 ( $p>0.05)$, and for daily goals scale is 1.342 ( $p>0.05)$, respectively. According to the results, all significance levels are greater than 0.05 and it is concluded that it is appropriate to use parametric tests.

\section{Hypotheses Tests}

\section{Difference Analysis}

Hypothesis 1 is to test whether motivation for individual instrument class differs by demographic variables or not. In order to determine the difference, independent samples t-test is employed when the variable is dyadic, i.e. university and gender in this case, and one way analysis of variance (ANOVA) test is employed when the variable has more than two categories, i.e. class and accommodation in this study.

In order to determine whether motivation for individual instrument class differs by university independent samples t-test is employed and the results are shown in Table 4. Totally, motivation for individual instrument class doesn't differ by university $(t=-1.623, p>0.05)$. However, amotivation significantly differs by university ( $\mathrm{t}=-2.370, \mathrm{p}<0.005)$. Amotivation levels of the students studying music teaching in Erzincan Binalı Yıldırım University are significantly higher than the ones attending Gazi University. 
Table 4. Result for H1-University

\begin{tabular}{|c|c|c|c|c|c|c|}
\hline Variable & University & $\mathbf{N}$ & Mean & Std.D. & t-Value & p \\
\hline \multirow{2}{*}{$\begin{array}{l}\text { Motivation for individual } \\
\text { instrument class }\end{array}$} & Gazi University & 149 & 3.11 & 0.28 & \multirow[t]{2}{*}{-1.623} & \multirow[t]{2}{*}{0.106} \\
\hline & Erzincan Binalı Yıldırım University & 76 & 3.19 & 0.50 & & \\
\hline \multirow{2}{*}{ Amotivation } & Gazi University & 149 & 1.42 & 0.67 & \multirow[t]{2}{*}{-2.731} & \multirow[t]{2}{*}{0.007} \\
\hline & Erzincan Binalı Yıldırım University & 76 & 1.72 & 0.97 & & \\
\hline \multirow{2}{*}{ Motivation for achievement } & Gazi University & 149 & 4.54 & 0.61 & \multirow[t]{2}{*}{1.059} & \multirow[t]{2}{*}{0.292} \\
\hline & Erzincan Binalı Yıldırım University & 76 & 4.42 & 0.91 & & \\
\hline \multirow{2}{*}{ Motivation for Study } & Gazi University & 149 & 3.61 & 0.97 & \multirow[t]{2}{*}{-0.457} & \multirow[t]{2}{*}{0.650} \\
\hline & Erzincan Binalı Yıldırım University & 76 & 3.67 & 0.96 & & \\
\hline
\end{tabular}

In order to determine whether motivation for individual instrument class differs by gender, independent samples t-test is employed and the results are shown in Table 5. Analysis results in that students' motivation for individual instrument class, in total and subfactors, doesn't differ by gender.

Table 5. Result for H1-Gender

\begin{tabular}{lllllll}
\hline \multicolumn{1}{c}{ Variable } & Gender & N & Mean & Std.D. & t-Value & p \\
\hline \multirow{2}{*}{ Motivation for individual instrument class } & Male & 117 & 3.13 & 0.40 & -0.345 & 0.730 \\
\cline { 2 - 5 } & Female & 108 & 3.14 & 0.34 & & \\
\hline \multirow{2}{*}{ Amotivation } & Male & 117 & 1.51 & 0.83 & -0.041 & 0.967 \\
\cline { 2 - 5 } Motivation for achievement & Female & 108 & 1.52 & 0.76 & & \\
\hline \multirow{2}{*}{ Motivation for Study } & Male & 117 & 4.48 & 0.73 & -0.388 & 0.699 \\
\cline { 2 - 5 } & Female & 108 & 4.52 & 0.72 & & \\
\hline
\end{tabular}

In order to determine whether motivation for individual instrument class differs by class, one way ANOVA is employed and the results are shown in Table 6. Analysis indicates that students' motivation for individual instrument class, in total and subfactors, doesn't differ by class.

Table 6. Result for H1-Class

\begin{tabular}{|c|c|c|c|c|c|c|}
\hline Variable & Student's Class & $\mathbf{N}$ & Mean & s.d. & $\mathbf{F}$ & $\mathbf{p}$ \\
\hline \multirow{4}{*}{$\begin{array}{l}\text { Motivation for individual } \\
\text { instrument class }\end{array}$} & Freshman & 63 & 3.21 & 0.33 & \multirow[t]{4}{*}{1.593} & \multirow[t]{4}{*}{0.192} \\
\hline & Sophomore & 64 & 3.14 & 0.32 & & \\
\hline & Middler & 57 & 3.10 & 0.39 & & \\
\hline & Senior & 41 & 3.06 & 0.45 & & \\
\hline \multirow{4}{*}{ Amotivation } & Freshman & 63 & 1.52 & 0.71 & \multirow[t]{4}{*}{0.081} & \multirow[t]{4}{*}{0.970} \\
\hline & Sophomore & 64 & 1.48 & 0.80 & & \\
\hline & Middler & 57 & 1.53 & 0.81 & & \\
\hline & Senior & 41 & 1.55 & 0.89 & & \\
\hline \multirow{4}{*}{ Motivation for achievement } & Freshman & 63 & 4.64 & 0.59 & \multirow[t]{4}{*}{1.989} & \multirow[t]{4}{*}{0.117} \\
\hline & Sophomore & 64 & 4.55 & 0.51 & & \\
\hline & Middler & 57 & 4.43 & 0.79 & & \\
\hline & Senior & 41 & 4.31 & 1.01 & & \\
\hline \multirow{4}{*}{ Motivation for Study } & Freshman & 63 & 3.71 & 0.81 & \multirow[t]{4}{*}{0.308} & \multirow[t]{4}{*}{0.819} \\
\hline & Sophomore & 64 & 3.65 & 0.99 & & \\
\hline & Middler & 57 & 3.57 & 1.03 & & \\
\hline & Senior & 41 & 3.56 & 1.07 & & \\
\hline
\end{tabular}


In order to determine whether motivation for individual instrument class differs by accommodation, one way ANOVA is employed and the results are shown in Table 7. Analysis indicates that students' motivation for individual instrument class, in total and subfactors, doesn't differ by accommodation.

Table 7. Result for H1-Accommodation

\begin{tabular}{|c|c|c|c|c|c|c|}
\hline Variable & Student's Class & $\mathbf{N}$ & Mean & s.d. & $\mathbf{F}$ & $\mathbf{p}$ \\
\hline \multirow{4}{*}{$\begin{array}{l}\text { Motivation for individual } \\
\text { instrument class }\end{array}$} & Staying with friends at home & 72 & 3.09 & 0.31 & \multirow[t]{4}{*}{2.218} & \multirow[t]{4}{*}{0.087} \\
\hline & Living with family & 82 & 3.10 & 0.44 & & \\
\hline & Staying at state run quarters & 39 & 3.26 & 0.39 & & \\
\hline & Staying at private sector quarters & 32 & 3.16 & 0.22 & & \\
\hline \multirow{4}{*}{ Amotivation } & Staying with friends at home & 72 & 1.39 & 0.72 & \multirow[t]{4}{*}{1.289} & \multirow[t]{4}{*}{0.279} \\
\hline & Living with family & 82 & 1.58 & 0.84 & & \\
\hline & Staying at state run quarters & 39 & 1.66 & 0.93 & & \\
\hline & Staying at private sector quarters & 32 & 1.45 & 0.59 & & \\
\hline \multirow{4}{*}{ Motivation for achievement } & Staying with friends at home & 72 & 4.49 & 0.70 & \multirow[t]{4}{*}{1.157} & \multirow[t]{4}{*}{0.327} \\
\hline & Living with family & 82 & 4.51 & 0.82 & & \\
\hline & Staying at state run quarters & 39 & 4.55 & 0.72 & & \\
\hline & Staying at private sector quarters & 32 & 4.68 & 0.41 & & \\
\hline \multirow{4}{*}{ Motivation for Study } & Staying with friends at home & 72 & 3.67 & 0.89 & \multirow[t]{4}{*}{1.470} & \multirow[t]{4}{*}{0.224} \\
\hline & Living with family & 82 & 3.51 & 1.05 & & \\
\hline & Staying at state run quarters & 39 & 3.88 & 1.02 & & \\
\hline & Staying at private sector quarters & 32 & 3.52 & 0.77 & & \\
\hline
\end{tabular}

\section{Regression Analysis}

In order to test $\mathrm{H} 2, \mathrm{H} 3$, and $\mathrm{H} 4$ hypotheses, initially correlation anaylsis is employed and results are given on Table 8. Analysis shows that there is a significant positive and moderate relationship between motivation for achievement and students' academic self-efficacy $(\mathrm{r}=0.180 ; \mathrm{p}<0.01)$. Similarly, there is a significant positive and moderate relationship between motivation for achievement and students' mindfulness $(\mathrm{r}=0.214 ; \mathrm{p}<0.01)$. On the other hand, there is no significant relationship between motivation for achievement and students' daily goals $(r=0.095 ; \mathrm{p}>0.05)$.

Table 8. Correlations among the Variables

\begin{tabular}{|c|c|c|c|c|c|}
\hline $\begin{array}{l}\text { Motivation for } \\
\text { Achievement }\end{array}$ & $\begin{array}{c}\text { Motivation } \\
\text { for Study }\end{array}$ & Amotivation & $\begin{array}{c}\text { Academic Self- } \\
\text { Efficacy }\end{array}$ & Mindfulness & Daily Goals \\
\hline
\end{tabular}

(1)

(2)

(3)

(4)

(5)

(6)

\begin{tabular}{lllllll}
\hline $\mathbf{1}$ & 1 & & & & & \\
\hline $\mathbf{2}$ & $0.610^{* *}$ & 1 & 1 & & & \\
\hline $\mathbf{3}$ & $-0.555^{* *}$ & $-0.419^{* *}$ & $-0.185^{* *}$ & 1 & & \\
\hline $\mathbf{4}$ & $0.180^{* *}$ & $0.260^{* *}$ & $-0.168^{*}$ & 0.118 & 1 & \\
\hline $\mathbf{5}$ & $0.214^{* *}$ & 0.111 & -0.071 & $0.417^{* *}$ & 0.104 & 1 \\
\hline $\mathbf{6}$ & 0.095 & $0.260^{* *}$ & &
\end{tabular}

* Correlation is significant at the 0.05 level (2-tailed).

** Correlation is significant at the 0.01 level (2-tailed).

Regarding motivation for study, the relationship between academic self-efficacy is significantly positive and moderate $(\mathrm{r}=0.260 ; \mathrm{p}<0.01)$. Likewise there is a significant positive and moderate relationship between 
motivation for study and daily goals $(\mathrm{r}=0.260 ; \mathrm{p}<0.01)$. But the relationship between motivation for study and mindfulness is not significant $(\mathrm{r}=0.111 ; \mathrm{p}>0.05)$. Concerning amotivation, it is found out that there is a significant negative and moderate relationship between amotivation and academic self-efficacy $(\mathrm{r}=-0.185$; $\mathrm{p}<0.01)$. In a similar vein, the relationship between amotivation and mindfulness significantly negative and moderate $(\mathrm{r}=-0.168 ; \mathrm{p}<0.05)$. However, there is no significant relationship between amotivation and daily goals $(\mathrm{r}=-0.071 ; \mathrm{p}>0.05)$.

In order to determine whether academic self-efficacy, mindfulness, and daily goals predict motivation for individual instrument class, multiple regression analysis is employed and analysis results are displayed on Table-9, 10, and 11, respectively.

Table 9. Regression Analysis-Amotivation

\begin{tabular}{|c|c|c|c|c|c|c|}
\hline Predictors & $\beta$ & S.E. & Std. $\beta$ & $\mathbf{F}$ & p & $\Delta \mathbf{R}^{2}$ \\
\hline Constant & $2.640^{* *}$ & 0.375 & & 4.375 & 0.05 & 0.056 \\
\hline Academic Self-Efficacy & $-0.198^{*}$ & 0.082 & -0.174 & & & \\
\hline Mindfulness & $-0.126^{*}$ & 0.056 & -0.149 & & & \\
\hline Daily Goals & 0.020 & 0.084 & 0.017 & & & \\
\hline
\end{tabular}

* Coefficient is significant at the 0.05 level (2-tailed).

** Coefficient is significant at the 0.01 level (2-tailed).

Table 9 displays regression analysis results for amotivation. Regression model is significant ( $\mathrm{F}=4.375$; $\mathrm{p}<0.05)$ and predicts $\% 5.6$ of variance in amotivation. Academic self-efficacy significantly and negatively predicts amotivation (Std. $\beta=-0.174 ; p<0.05)$ as mindfulness does (Std. $\beta=-0.149 ; p<0.05)$. On the other hand daily goals don't predict amotivation (Std. $\beta=0.017 ; \mathrm{p}>0.05$ ). That's to say, $\mathrm{H} 2$ is partially accepted.

Table 10. Regression Analysis-Motivation for Achievement

\begin{tabular}{|c|c|c|c|c|c|c|}
\hline Predictors & $\beta$ & S.E. & Std. $\beta$ & $\mathbf{F}$ & $\mathrm{p}$ & $\Delta \mathbf{R}^{2}$ \\
\hline Constant & $3.323^{* *}$ & 0.339 & & 5.579 & 0.01 & 0.07 \\
\hline Academic Self-Efficacy & $0.157^{*}$ & 0.074 & 0.153 & & & \\
\hline Mindfulness & $0.150^{* *}$ & 0.050 & 0.195 & & & \\
\hline Daily Goals & 0.012 & 0.076 & 0.011 & & & \\
\hline
\end{tabular}

Table 10 displays regression analysis results for motivation for achievement. Regression model is significant $(\mathrm{F}=5.579 ; \mathrm{p}<0.01)$ and predicts $\% 7$ of variance in motivation for achievement. Academic self-efficacy significantly and positively predicts motivation for achievement (Std. $\beta=0.157 ; p<0.05$ ) as mindfulness does (Std. $\beta=0.150 ; p<0.05$ ). On the other hand daily goals don't predict motivation for achievement (Std. $\beta=0.011$; $\mathrm{p}>0.05)$. That's to say, H3 is partially accepted.

Table 11. Regression Analysis-Motivation for Study

\begin{tabular}{|c|c|c|c|c|c|c|}
\hline Predictors & $\beta$ & S.E. & Std. $\beta$ & $\mathbf{F}$ & $\mathrm{p}$ & $\Delta \mathbf{R}^{2}$ \\
\hline Constant & $1.491^{* *}$ & 0.445 & & 8.248 & 0.00 & 0.101 \\
\hline Academic Self-Efficacy & $0.244^{*}$ & 0.097 & 0.177 & & & \\
\hline Mindfulness & 0.126 & 0.066 & 0.071 & & & \\
\hline Daily Goals & $0.254^{*}$ & 0.100 & 0.179 & & & \\
\hline
\end{tabular}


Table 11 displays regression analysis results for motivation for study. Regression model is significant $(\mathrm{F}=8.248 ; \mathrm{p}<0.01)$ and predicts $\% 10.1$ of variance in motivation for study. Academic self-efficacy significantly and positively predicts motivation for study (Std. $\beta=0.177 ; p<0.05$ ) as daily goals does (Std. $\beta=0.179 ; p<0.05$ ). On the other hand mindfulness doesn't predict motivation for study (Std. $\beta=0.071 ; p>0.05$ ). That's to say, H4 is partially accepted.

\section{Discussion and Conclusion}

Music education is a comprehensive and diversified branch for the students studyin music teaching at faculty of education. On one hand the students are expected to learn how to create an effective learning atmosphere, on the other hand they are to make music a living part of pupils. Under this responsibility, students need to study hard, acquire playing skills, and teaching abilities. It is very important and necessary for the music teacher candidate to prepare for the profession and to be a successful music educator with the courses given under the name of "individual instrument class" in the institutions of the universities training music teachers. Therefore, one of the most indispensable branches of music education is individual instrument playing, which contributes to the concrete development of musical perception ability and requires the use of musical education, psychomotor and emotional skills together.

In order to produce successful performances, instrument training is a planned, intensive and regular performance course that requires long hours of practice in a certain discipline, and it is very important to continue the practices regularly without any interruption. When the practicing is somehow disrupted, it is reflected negatively on the performance of the instrument as soon as possible. According to social cognitive theory, performance is a multi-functional construct including the beliefs of the student, the school, and environmental factors. Towards this end, there is an ever growing interest in education research on the factors affecting learning during university life. One of the factors, recently attached significance, is self-regulating strategies of students studying music teaching to motivate themselves for individual instrument class. Particularly, students would be efficiently motivated if the factors that affect the requirements were determined (Küçükosmanoğlu, 2015). Girgin (2015) is the first study to research motivation for individual instrument class in Turkish cultural context. Then, Girgin (2017), Gerçeker (2018), and Herdem (2019) measures the effect of different variables on motivation for individual instrument class. Common point of the studies is the need for further studies in order to more clarify the literature on motivation for individual instrument class. To this end, this study aims at contributing to the literature on motivation for individual instrument class by determining, describing, explaining, and predicting it by means of a cross-sectional survey-based empirical study.

Data on demographic information, motivation for individual instrument class, academic-self-efficacy, mindfulness, and daily goals were gathered through a self-reported questionnaire in Gazi University and Erzincan Binali Yıldırım University. SPSS and AMOS softwares were employed to analyse data on a sample of 225 students studying music teaching. The construct validity was analyzed by CFA and Cronbach Alpha coefficient was employed to test the reliability. Three-factor related model for motivation for individual instrument and one factor models for academic-self-efficacy, mindfulness, and daily goals were confirmed. Amotivation, motivation for achievement, and motivation for study are three subfactors as proposed by Girgin (2015).

Analysis indicated that amotivation levels of students is lower while motivation for achievement is higher and motivation for study is average. The studies such as Küçükosmanoğlu (2015), Şeker (2017), and Herdem (2019) report quite similar motivation levels with the current study. On the other hand, Şeker (2017) advocates that an average motivation level is not sufficient for students studying teaching. Main reason for amotivation is having no idea how to choose convenient learning strategy for different situations (Tuckmann, 1999). However, the studies show that university students studying music teaching are motivated to acquire 
playing skills as well as teaching abilities. Because instrument playing education takes long hours and requires high physical performance as well as psychological performance, having the will to act is one of main factors to develop performance skills in playing an instrument as a part of music education. Thus, it is critical to study the determinants of motivation of students related to their study areas.

In order to test the hypotheses, independent samples t-test, one way ANOVA, correlation and regression analyses were employed in the study. Regarding H1, only amotivation levels of the students differ by university where motivation for individual instrument class doesn't differ by gender, class, and accommodation. Similarly, motivation levels of students don't differ by gender according to Şeker (2017) and Herdem (2019). In addition, regarding class of the students, Eroğlu and colleagues (2017), and Şeker (2017) reveal that academic motivation doesn't differ by class. On the other hand, Herdem (2019) reports no significance difference related to university. Accommodation is newly introduced in this study to determine whether motivation is differentiated. It is concluded that motivation levels of students for individual instrument class doesn't differ by accommodation. Possible reason for differentiation according to university for amotivation may be the cities where universities are located. Amotivation levels of students attending Erzincan Binalı Yıldırım University is lower that the ones enrolled in Gazi University. Ankara, where Gazi University is situated, provides more social activities promoting quality of life.

Regarding $\mathrm{H} 2, \mathrm{H} 3$, and $\mathrm{H} 4$, correlation analysis show that academic self-efficacy is significantly associated with three subfactors at moderate levels while mindfulness is significantly associated with amotivation and motivation for achievement and daily goals is associated with amotivation and achievement for study. Likewise results of regression analysis are consistent with correlation analysis. Significant standardized coefficients with regard to regression analysis are depicted on Figure 2.

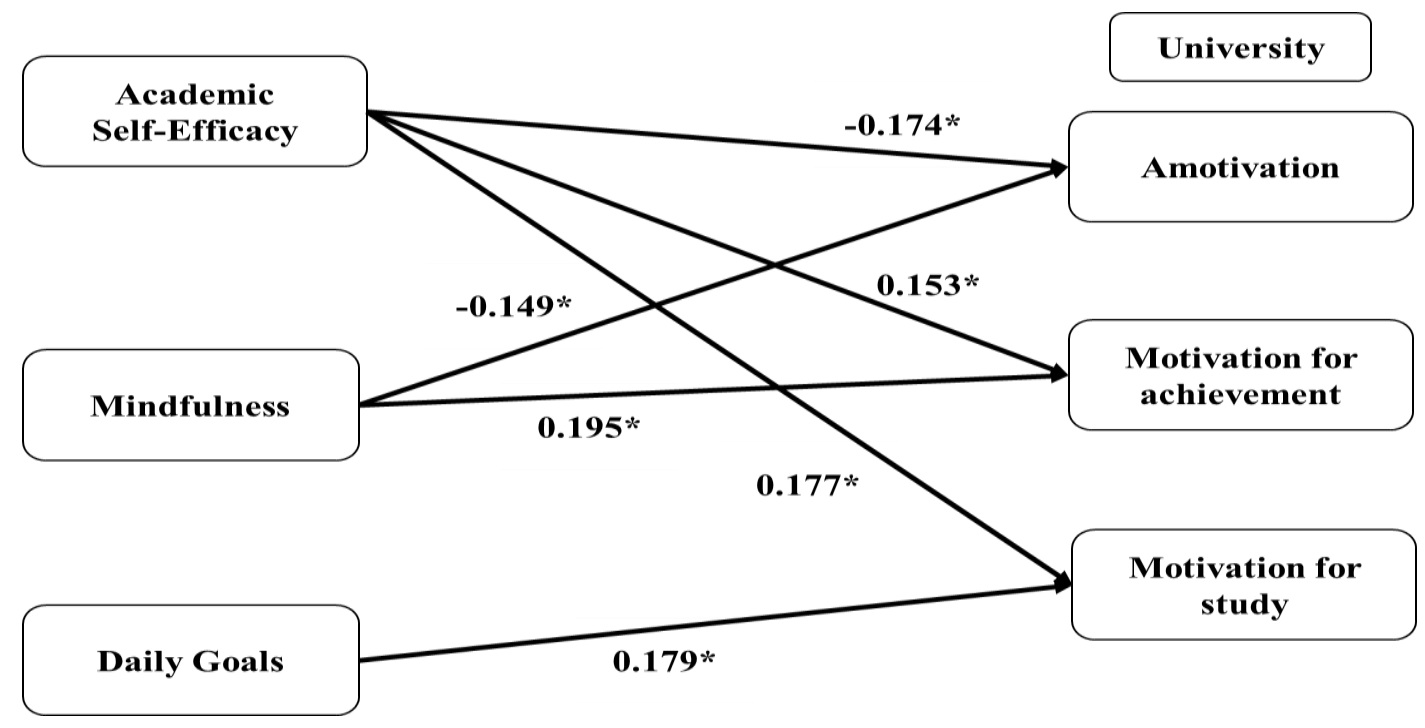

Figure 2. Result of the Study

Regression analysis reveal that academic self-efficacy significantly and negatively affects amotivation while the effects on motivation for achievement and study are significantly positive. Hence, it is concluded that $\mathrm{H} 2$ is accepted. This finding is in compliance with many studies in literature (e.g. Schunk, 1991; Bandura, 1993, 1997; Zimmerman \& Kitsantas, 1999; Schunk \& Pajares, 2002; Hsieh et al., 2007; Alivernini \& Lucidi, 2011; McGeown et al., 2014; Hwang et al., 2015; Eroğlu et al., 2017; Şeker, 2017; Arık, 2019).

It is also found out that mindfulness significantly and negatively affects amotivation while positively affects motivation for achievement. Thus H3 is partially accepted. This finding is in compliance with Sukhsarwala et al. (2015), Corti \& Gelati, 2019, and Pohl, 2020. And Zimmerman (2000) highly recommends 
teachers to promote self-efficacy in order to motivate the students to learn. Mindfulness is the most prominent predictor that interacts with learning stragies (Kocaarslan \& Otacıoğlu, 2018). Furthermore, mindfulness is becoming an indispensable part of many systems including education (Roeser, 2014). Once mindfulness affects motivation, students are expected to transform emotional reactivity skill into emotional regulation (Roeser, 2016, p. 391). Zhang, Solmon and Gu (2012) concede that supportive learning environment created by teacher assigning subjective tasks according to students' competencies is positively associated with students' achievement goals. Likewise, motivation asks for enjoyable and interesting design of the class, teachers may be innovative and creative to make the lesson more interesting to increase participation. Teaching the students to learn how to learn may strengthen the mindsets of the student. Moreover, mindfulness based program would assist students to be motivated through academic achievement and help the students to improve selfconfidence regarding learning abilities. Therefore, reorganization of syllabus of individual intrument class involving mindfulness practices may speed up skill acquisition process and facilitate to motivate to achieve long-term goals. Towards this end, it is considered appropriate to plan and organize practices and seminars on mindfulness to the students. In this context, it might be beneficial to plan elective courses under the title of "mindful practices in musical education".

In a similar vein, $\mathrm{H} 4$ is partially accepted because daily goals significantly and positively affect motivation for study. This finding is in compliance with Zimmerman et al. (1992), Schunk (1995), King (2016), Mikami (2017), and Zhang et al. (2019). Motivation in schools is a process affected by individuals' as well as contextual factors such as learning environment (Ennis, 2017, p. 245). Motivation for a student is the degree of influence on the self to continue school life and attain the desired grade (Clark \& Schroth, 2010). Then, it is not wrong to say that in order for students to actively participate in learning process and to have the will to improve skills require high motivation (Şeker, 2017). The study results indicate that motivation for achievement is higher than motivation for study. And while mindfulness significantly affects motivation for achievement, daily goals significantly affects motivation for study. In fact, motivation directs individual through specific goals and urge them to achieve the desired end state. Regular long-term practice is required in acquisition of skills to play an individual instrument. Thus, it is reasonable to investigate mediation role of daily goals in the relation between mindfulness and motivation for individual instrument class since shortterm goal setting is a bridge for long-term achievements.

Also, there are some limitations of the study. Initially, the sample of the study is from the students studying at universities located in two universities. That's why researchers are highly asked to repeat this study's research model with larger samples. Second, design of this study is cross-sectional design. Thus, the findings are related to the psychology for the participants at the time measured. Therefore, longitudinal studies are motivated in order to extend the findings. In this context, experimental studies can be conducted on the effect of setting daily goals on success in individual instrument education. Once goals affect behaviors through motivation (Locke \& Latham, 1990), it is convenient to extend the study by introducing new variables related with academic success, quality of life, and professional experience. Last but not least, participants may answer the questionnaire according to their ecpectations rather than current situations. Therefore, it is significant that limitations may be kept in mind while findings are generalized. 


\section{REFERENCES}

Alivernini, F., \& Lucidi, F. (2011). Relationship between social context, self-efficacy, motivation, academic achievement, and intention to drop out of high school: A longitudinal study. The Journal of Educational Research, 104(4), 241-252.

Arık, S. (2019). The relations among university students' academic self-efficacy, academic motivation, and selfcontrol and self-management levels. International Journal of Education and Literacy Studies, 7(4), 23-34.

Baer, R. A., Smith, G. T., \& Allen, K. B. (2004). Assessment of mindfulness by self-report: The Kentucky Inventory of Mindfulness Skills. Assessment, 11(3), 191-206.

Bakioğlu, F., \& Çapan, B.,E. (2015). Günlük amaçlar ölçeği: Türkçe formunun psikometrik özellikleri. Anatolian Journal of Psychiatry, 16(1),64-72.

Bandura, A. (1977). Self-efficacy: Toward a unifying theory of behavioral change. Psychological review, 84(2), 191-215.

Bandura, A. (1993). Perceived self-efficacy in cognitive development and functioning. Educational Psychologist, 28(2), 117-148.

Bandura, A. (1994). Self-efficacy. In V. S. Ramachaudran (Ed.), Encyclopedia of Human Behavior (Vol. 4, pp. 7181). New York: Academic Press.

Bandura, A. (1997). Self-efficacy: The exercise of control. New York: Freeman.

Bandura, A. (2012). On the functional properties of perceived self-efficacy revisited. Journal of Management, $38(1), 9-44$.

Bishop, S. R., Lau, M., Shapiro, S., Carlson, L., Anderson, N. C., Carmody, J., et al. (2004). Mindfulness: A proposed operational definition. Clinical Psychology: Science and Practice, 11, 230-241.

Brophy, J. (1998). Motivating students to learn. Madison. WI: McGraw Hill.

Brown, K. W., \& Ryan, R. M. (2003). The benefits of being present: mindfulness and its role in psychological well-being. Journal of Personality and Social Psychology, 84(4), 822.

Browne, M. W., \& Cudeck, R. (1993). Alternative ways of assessing model fit, Bollen K.A., \& Long J.S. (Ed.), Testing Structural Equation Models (pp. 136-162). Thousand Oaks: Sage.

Byrne, B. M. (2001). Structural equation modeling with AMOS, EQS, and LISREL: Comparative approaches to testing for the factorial validity of a measuring instrument. International Journal of Testing, 1(1), 55- 86.

Corti, L., \& Gelati, C. (2020). Mindfulness and coaching to improve learning abilities in university students: A pilot study. International Journal of Environmental Research and Public Health, 17(6), 1935, 1-20.

Demir, V. (2017). Bilinçli farkındalık temelli bilişsel terapi programının üniversite öğrencilerinin kayg1 düzeylerine etkisi. Uluslararası Toplum Araştırmaları Dergisi, 7(12), 98-122.

Deniz, J., \& Kürücü, N. (2019). Müzik öğretmeni adaylarının müzik öğretimi öz yeterlilik algılarının incelenmesi. Akademik Sosyal Araştırmalar Dergisi, 6(34), 112-126.

Emmons, R.,A, Colby, P.,M., \& Kaiser H.,A. (1998). When losses lead to gains: personal goals and recovery of meaning. In P. Wong, \& P. Fry (Eds.), The human quest for meaning: A handbook of psychological research and clinical applications (pp.163-178). Mahwah, N. J.: Lawrence Erlbaum Associates.

Ennis, C. D. (2017). Educating students for a lifetime of physical activity: Enhancing mindfulness, motivation, and meaning. Research Quarterly for Exercise and Sport, 88(3), 241-250.

Eroğlu, O., Yıldırım, Y., \& Şahan, H. (2017). Spor bilimleri fakültesindeki öğrencilerin akademik öz-yeterlik ve akademik güdülenme düzeyleri arasındaki ilişkinin incelenmesi: Akdeniz Üniversitesi örneği. Türkiye Spor Bilimleri Dergisi, 1(1), 38-47.

Ersanl1, C. Y. (2015). The relationship between students' academic self-efficacy and language learning motivation: A study of 8th graders. Procedia-Social and Behavioral Sciences, 199, 472-478. 
Gerçeker, C. S. (2018). Investigation of music teacher candidates' individual instrument burnout, perceived family support in instrument training and individual instrument training habits with regard to various variables. Educational Research and Reviews, 13(12), 447-463.

Girgin, D. (2015). Bireysel çalg1 dersi motivasyon ölçeği: Geçerlik güvenilirlik analizi, Kastamonu Ĕ̆gitim Dergisi, 23(4), 1723-1736.

Girgin, D. (2017). Müzik öğretmeni adaylarının çalgı performansı özyeterlik inancı düzeylerinin çeşitli değişkenlere göre incelenmesi. Ahi Evran Üniversitesi Kırşehir Eğitim Fakültesi Dergisi, 18(1), 613-624.

Herdem, D., Ö. (2018). Çalg1 eğitiminde zamanı etkili ve verimli kullanma ile akademik başarı arasındaki ilişki ve bir teknik öneri: Gazi Üniversitesi Eğitim Fakültesi örneği. Turkish Studies Educational Sciences. 13(26), 941-952.

Herdem, D., Ö. (2019). The effect of psychological capital on motivation for individual instrument: A study on university students. Universal Journal of Educational Research, 7(6), 1402-1413.

Hsieh, P., Sullivan, J. R., \& Guerra, N. S. (2007). A closer look at college students: Self-efficacy and goal orientation. Journal of Advanced Academics, 18(3), 454-476.

Hwang, M. H., Choi, H. C., Lee, A., Culver, J. D., \& Hutchison, B. (2015). The relationship between selfefficacy and academic achievement: A 5-Year Panel Analysis. The Asia-Pacific Education Researcher, 25(1), 89-98.

Jerusalem, M. (2002). Theroretischer Teil-einleitung. Zeitschrift für Pädagogik, 44, 8-12.

Kabat-Zinn, J. (1994). Wherever you go there you are. New York: Hyperion.

Kabat-Zinn, J. (2000). Indra's net at work: The mainstreaming of Dharma practice in society. In G. Watson, \& S. Batchelor (Eds.), The psychology of awakening: Buddhism, science, and our day-to-day lives (pp. 225-249). North Beach, ME: Weiser.

King, R. B. (2016). Is a performance-avoidance achievement goal always maladaptive? Not necessarily for collectivists. Personality and Individual Differences, 99, 190-195.

King, L. A., Richards, J. H., \& Stemmerich, E. (1998). Daily goals, life goals, and worst fears: Means, ends, and subjective well-being. Journal of Personality, 65, 713-744.

Kline, R. B. (2004). Principles and Practice of Structural Equation Modeling, New York: Guilford.

Kocaarslan, B., \& Otacıoğlu, S.,G. (2018). Profesyonel müzik eğitimi alan lisans öğrencilerinin, bilinçli farkındalık ve öğrenme stratejileri düzeyleri arasındaki ilişkiler. Social Sciences Studies Journal, 4(24), 49114921.

Küçükosmanoğlu, H. (2015). Müzik öğretmeni adaylarının akademik motivasyon düzeylerinin belirlenmesi üzerine bir çalışma (Konya ili örneği). Sanat Ĕ̆itimi Dergisi, 3(1), 1-21.

Levesque, C., \& Brown, K. W. (2007). Mindfulness as a moderator of the effect of implicit motivational selfconcept on day-to-day behavioral motivation. Motivation and Emotion, 31(4), 284-299.

Linehan, M. (1993). Cognitive-behavioral treatment of borderline personality disorder. New York: Guilford.

Lykins, E. L., \& Baer, R. A. (2009). Psychological functioning in a sample of long-term practitioners of mindfulness meditation. Journal of cognitive Psychotherapy, 23(3), 226-241.

Locke, E. A., \& Latham, G. P. (1990). A theory of goal setting and task performance. Englewood Cliffs, NJ: PrenticeHall.

McGeown, S. P., Putwain, D., Simpson, E. G., Boffey, E., Markham, J., \& Vince, A. (2014). Predictors of adolescents' academic motivation: Personality, self-efficacy and adolescents' characteristics. Learning and Individual Differences, 32, 278-286.

Mikami, Y. (2017). Relationships between goal setting, intrinsic motivation, and self-efficacy in extensive reading. JACET Journal, 61, 41-56.

Nunnaly, J. (1978). Psychometric Theory. New York: McGraw-Hill.

Onuk, Ö. (2007). Müzik öğretmenliği lisans programı öğrencilerinin öğretmenliğe güdülenmeleri ile akademik başarıları arasındaki ilişki (Yayımlanmamış Doktora Tezi). Ankara: Gazi Üniversitesi Sosyal Bilimler Enstitüsü. 
Özyeşil, Z., Arslan, C., Kesici, Ş., Deniz, M.,E. (2011). Bilinçli farkındalık ölçeğini uyarlama çalışması. Eğitim ve Bilim, 36(160), 225.

Öncü, H. (2012). Akademik öz yeterlik ölçeğinin Türkçeye uyarlanması. Ahi Evran Üniversitesi Kırşehir Eğitim Fakültesi Dergisi (KEFAD), 13( 1), 183-206.

Pajares, F. (1996). Self-Efficacy beliefs in academic settings. Review of Educational Research, 66(4), 543-578.

Pintrich, P. R., \& Schunk, D. (2002). Motivation in education: Theory, research, and applications (2nd ed). Upper Saddle River, N. J.: Merril Prentice Hall.

Pohl, A. J. (2020) Strategies and interventions for promoting cognitive engagement. In A. Reschly, A. Pohl, S. Christenson (eds) Student Engagement. Cham: Springer.

Prinz, W., Beisert, M., \& Herwig, A. (Eds.). (2013). Action science: Foundations of an emerging discipline. Cambridge, MA: MIT Press.

Roeser, R. W. (2014). The emergence of mindfulness-based interventions in educational settings. In T. Urdan, \& S. Karabenick (Eds.), Motivational interventions (pp. 379-419). Bingley, UK: Emerald Group.

Roeser, R. W. (2016). Mindfulness in students' motivation and learning in school. Handbook on Motivation at School (pp. 385-407).

Sak, Ö.,S. (1997). Illköğretim Okullarında Müzik Eğitimi ve Çocuk Şarkıları Üzerine Bir Araştırma (Yayınlanmamış Yüksek Lisans Tezi). Konya: Selçuk Üniversitesi Eğitim Bilimleri Enstütüsü.

Sabuncuoğlu, Z., \& Tüz, M. V. (1998). Örgütsel psikoloji. İstanbul: Alfa Basım Yayım Dağıtım.

Schumacher R.E., \& Lomax R.G.,(2004). A beginner's guide to SEM (2nd ed.). New Jersey: Lawrenge Erlbaum Associotes Publishers.

Schunk, D. H. (1991). Self-efficacy and academic motivation. Educational Psychologist, 26(3/4), 207-231.

Schunk, D. H. (1995). Self-efficacy, motivation, and performance. Journal of Applied Sport Psychology, 7(2), 112137.

Schunk, D. H., \& Pajares, F. (2002). The development of academic self-efficacy. In A. Wigfield, \& J. Eccles (Eds.), Development of achievement motivation (pp. 15-31). San Diego: Academic Press.

Schunk, D. H., \& Pajares, F. (2009). Self-efficacy theory. In K. R. Wentzel, \& A. Wigfield (Eds.), Handbook of motivation at school (pp. 35-54). London: Routledge.

Sternberg, R. J. (2002). Raising the achievement of all students: Teaching for successful intelligence. Educational Psychology Review, 14(4), 383-393.

Sternberg, R. J., \& Williams, W.M. (2002). Educational psychology. Boston, MA: Allyn \& Bacon.

Sungurtekin, K. M. (2010). Motivasyon ve çalg1 eğitimindeki yeri. Fine Arts, 5(1), 28-34.

Sukhsarwala, B., Kacker, P., \& Mukundan, C. R. (2015). Academic motivation, dispositional mindfulness, emotional maturity and academic achievement of college students. International Journal of Management $\mathcal{E}$ Behavioural Sciences, 6(7), 282-296.

Şeker, S. S. (2017). Müzik eğitimi bölümü öğretmen adaylarının akademik güdülenme ve akademik öz-yeterlik düzeylerinin incelenmesi. Abant İzzet Baysal Üniversitesi Ĕ̆itim Fakültesi Dergisi, 17(3), 1465-1484.

Tuckman, B.W. (1999). A tripartite model of motivation for achievement: Attitude/drive/strategy. Paper presented in the symposium: Motivational factors affecting student achievement-current perspectives. Annual Meeting of the American Psychological Association, Boston.

Uçan, A. (2017). Türkiye' de müzik araştırmalarına genel bir bakış ve KKÜ I. ulusal müzik araştırmaları öprenci kurultayı. Çevrim İçi Müzik Bilimler Dergisi, 2(3), 9-36.

Üstün, E. (2019). Flüt eğitiminde günlük çalışma yapmanın öğrenciler üzerinde bilinçli farkındalık ve stres kontrolü açısından etkisi, Türkiye Sosyal Araştırmalar Dergisi, 23(2), 591-601.

Valerio, K. (2012). Intrinsic motivaiton in the classroom. Journal of Student Engagement: Education Matters, 2(1), 30-35.

Weinstein, N., Brown, K. W., \& Ryan, R. M. (2009). A multi-method examination of the effects of mindfulness on stres attribution, coping, and emotional well-being. Journal of Research in Personality, 43, 374-385. 
Zhang, J., Cao, C., Shen, S., \& Qian, M. (2019). Examining effects of self-efficacy on research motivation among chinese university teachers: moderation of leader support and mediation of goal orientations. The Journal of Psychology, 153(4), 414-435.

Zhang, T., Solmon, M. A., \& Gu, X. (2012). The role of teachers' support in predicting students' motivation and achievement outcomes in physical education. Journal of Teaching in Physical Education, 31, 329-343.

Zimmerman, B. J. (2000). Self-efficacy: An essential motive to learn. Contemporary Educational Psychology, 25(1), 82-91.

Zimmerman, B. J., Bandura, A., \& Martinez-Pons, M. (1992). Self-motivation for academic attainment: The role of self-efficacy beliefs and personal goal setting. American Educational Research Journal, 29(3), 663-676.

Zimmerman, B. J., \& Kitsantas, A. (1999). Acquiring writing revision skill: Shifting from process to outcome self-regulatory goals. Journal of Educational Psychology, 91, 1-10. 